\title{
Heat Penetration Characteristics and Shelf Life of Ready to Serve Eel Curry in Retort Pouch
}

\author{
Rohini Mugale*, S.B. Patange, V.R. Joshi, G.N. Kulkarni and M.M. Shirdhankar \\ College of Fisheries, Dr. B. S. Konkan Krishi Vidyapeeth, Ratnagiri-415629, \\ Maharashtra, India \\ *Corresponding author
}

\begin{tabular}{|l|}
\hline K e y w or d s \\
$\begin{array}{l}\text { M. armatus, } \\
\text { Texture profile } \\
\text { analysis, Cook } \\
\text { value, F0 value, } \\
\text { Storage studies }\end{array}$ \\
\hline Article Info \\
\hline $\begin{array}{l}\text { Accepted: } \\
\text { xx January } 2018 \\
\text { Available Online: } \\
\text { xx February } 2018\end{array}$ \\
\hline
\end{tabular}

A B S T R A C T

Ready to serve thermal processed eel fish curry was developed using eel steaks (Mastacembalus armatus). The eel curry was packed in an indigenously developed four layered laminated retortable pouch consisting of 12 micron polyester / 9 micron aluminium foil / 5 micron nylon / 70 micron cast polypropylene of size 150x $200 \mathrm{~mm}$ and processed in a steam air retort at $121^{\circ} \mathrm{C}$. The curry and eel steaks were packed in 60:40 proportion. Time-temperature data from sealed samples was collected during heat processing using a 'Nano Vacq 1 Tc' data logger to record the data during processing. The product was processed for 2,3 and $4 \mathrm{~min}$ at $121^{\circ} \mathrm{C}$ at the process value of 5.03, 12.89 and $16.75 \mathrm{~min}$ respectively. Further, product was analyzed for textural attributes like cohesiveness toughness, succulence and fibrosity and sensory analysis. Based on these analyses, it was observed that, the product processed for $3 \mathrm{~min}\left(\mathrm{~F}_{0}\right.$ value of $\left.12.89 \mathrm{~min}\right)$ with total process time of 55min and cook value 97.65 min gave better textural and sensory characteristics and the product was commercially sterile. The product processed for 3 min was kept for storage to evaluate the shelf life for a period of 8 months. During storage at ambient temperature, biochemical parameters like $\mathrm{pH}, \mathrm{TVB}-\mathrm{N}$ and organoleptic characteristics like appearance, colour, taste, odour and overall acceptability were evaluated. During storage like $\mathrm{pH}$ value decreased from 6.7-5.8, whereas TVB-N values increased from 4.20 - 17.07 $\mathrm{mg} \%$. The sensory scores for all attributes were decreasing during storage. The product was acceptable for a period of 7 months at ambient temperature of $30 \pm 2^{\circ} \mathrm{C}$.

\section{Introduction}

Thermal processing seems to be a good alternative to obtain a shelf-stable product with good nutritional value. Scarce information is available about the effects of thermal processing on the nutritional value of eel (M. armatus). There is an increasing consumer demand for high quality convenient ready-to-eat food products and has led to an increase in the commercial production of ready-to-eat products (Kumar et al., 2013). Retort pouch processing technology has been widely recognized as one of the alternatives to metal cans for producing thermal processed shelf stable foods. Value addition and diversification to satisfy the ever changing and diverse demands from the importing countries as well as urban consumers at home are some of the major challenges faced by the Indian 
fish processing industry (Manju et al., 2004). Traditionally processed ready-to-eat foods packed in tin and aluminium cans have their own disadvantages like higher price of container, development of metallic flavour and discolouration in the product (Vijayan and Balachandran, 1986). Retort pouch is flexible, laminated package that can withstand thermal processing and has the advantages of cans as well as flexible packages. Thin profile containers like retort pouch facilitate larger surface area which helps to increase the rate of heat transfer into the food and reduce process time and maximize the retention of quality factors of the fish product (Bindu et al., 2011).

Gopal et al., (1986) have studied the suitability of flexible pouch for packing fish pickles. A new packaging medium namely curry was suggested as an alternative to the conventional brine and oil pack for different species of fish (Vijayan and Balachandran, 1986; Vijayan et al., 1998). Bindu et al., (2001) have studied thermal processing of ready to serve masmin curry from skipjack tuna in opaque retortable pouches.

Similar studies were also reported on standardization of ready-to-serve curry products in retort pouch by Gopal et al., (2001) studied the ready-to-serve traditional Kerala style mackerel curry in retort pouch, Ravishankar et al., (2002) have studied heat processing and storage of seer fish curry in retort pouches, Manju et al., (2004) studied the suitability of retort pouches for seer fish moilee, Ravishankar et al., (2008) studied the ready to serve Goan style mackerel curry in retort pouches, Dhanapal et al., (2010) studied the quality of ready to serve tilapia fish curry with PUFA in retortable pouches, Mallick et al., (2010) observed the instrumental and sensory characteristics of Indian white shrimp in curry medium in retort pouch, Bindu et al., (2011) studied the heat penetration characteristics and shelf life of ready to serve mahaseer curry in opaque retortable pouches and Dileep et al., (2012) have studied the retortable pouch processed squid rings in curry medium, Majumdar et al., (2014) have observed the instrumental and sensory characteristics of catla curry in retort pouch to optimize $\mathrm{F}_{0}$ value.

One of the main features in appreciating seafood is the texture (Cheret et al., 2005). Texture is rated as an important quality attribute of meat. The importance of texture on the overall acceptability of foods is well known and it directly affects the acceptance by consumers (Xavier et al., 2013). It is also a structural, mechanical and surface properties of foods detected through the sense of vision, hearing, touch and kinesthetic (Szczesniak, 2002).

Present market trends are indicative of extensive demand for ready to cook or ready to serve convenience products processed out of a wide variety of fish and shell fish. One of the ready to serve products is fish curry.

Hence, attempts were made to develop a process for the preparation of eel curry in retort pouches and to study its shelf life and quality characteristics at ambient temperature.

\section{Materials and Methods}

\section{Raw material}

Fresh eel were obtained from the Ratnagiri fish market. Fishes were put in ice in the ratio of 1:1 (fish: ice) and transported to laboratory in insulated containers.

The fishes were washed thoroughly in potable water and cut into steaks of $4-5 \mathrm{~cm}$ size, using knife. In order to remove slime and blood and increase the firmness of fish muscle during thermal processing, these eel steaks were used for the preparation of eel in curry product. 
Proximate composition of fresh eel fish meat

Proximate composition i.e. crude protein, crude fat, moisture and ash of the eel fish were analyzed by AOAC (2005) methods.

\section{Preparation of eel curry}

Eel curry was prepared following the recipe given in Table 1. The standardized recipe of curry medium was prepared according to Patange et al., (2016). Air from the filled pouch was exhausted by steam flushing (Madhawaraj et al., 1992) and sealed immediately using an impulse heat-sealing machine. These pouches were further processed in an overpressure retort.

\section{Retort pouch}

Laminated flexible pouch (4-ply), consisting of 12 micron polyester (outer layer), 9 micron aluminium foil and 15 micron nylon (middle layer) and 70 micron polypropylene (inner cast) was used for packing the fish curry. Pouches $(150 \times 200 \mathrm{~mm})$ used in the present study were purchased from M/s. Pradeep Laminators Pvt. Ltd. Pune. Maharastra, India.

\section{Overpressure retort}

A steam air retort system (KVP Enterprise, TN) was used for the experiment. The retort was operated in the steam/air mixture mode during the sterilization cycle. For heat penetration studies pouches were fixed with thermocouple gland through which thermocouples were inserted. Thermocouple output was measured using 'Nano Vacq 1 Tc' data logger to record the data during processing. The retort temperature was maintained at $121{ }^{\circ} \mathrm{C}$ throughout the heating period. After processing the pouches to required $F_{0}$ value, they were cooled rapidly to prevent overcooking as well as survival of any thermophiles (Ravishankar et al., 2002) till the core temperature of the product reached $55^{\circ} \mathrm{C}$ by pumping water into the retort and recirculating it. On completion of retorting wireless data logger was removed from pouch and recorded dada was analyzed by using software 'Qlever 2 lite' to calculate process value and process time.

\section{Thermal process evaluation}

Heat penetration data were plotted on a semi $\log$ paper with temperature deficit i.e. Retort temperature - Core temperature (RT-CT) on $\log$ scale against time. Slope of heating curve $\left(\mathrm{f}_{\mathrm{h}}\right)$, time in minutes for sterilization at retort temperature $(\mathrm{U})$, final temperature deficit $(\mathrm{g})$ and cook value $(\mathrm{Cg})$ were determined. The process time (B) was calculated by the formula method (Stumbo, 1973). Total process time was determined by adding process time (B) and the effective heating period during come up time i.e. $42 \%$ of comeup time of the product. The $F_{0}$ value is used as a basis for comparing heat sterilization procedures. It represents the total timetemperature combination received by a food. Among the three different durations (2, 3 and $4 \mathrm{~min}$ ) tried, the product processed for $3 \mathrm{~min}$ was found to have better sensory attributes and textural property and hence samples processing at $121^{\circ} \mathrm{C}$ for $3 \mathrm{~min}$ was chosen for the studies.

\section{Texture profile analysis}

The texture profile analysis (TPA) was performed using a cylindrical probe of $5 \mathrm{~mm}$ diameter fitted with load cell. Eel steaks were cut into $2.5 \mathrm{~cm}$ block for analysis of texture profile. The textural characteristics such as; cohesiveness (ratio of energies expanded in the first and second cycles), toughness, succulence and fibrosity were evaluated after heat penetration study of eel in curry processed at three different durations of 
processing for 2,3 and $4 \mathrm{~min}$. The product were analyzed based on compression of samples with Texture analyzer (Perten Instrument, Sweden; model TVT-300XP) with TexCal texture analyzer software (version 4.0.2.50), was used to objectively evaluate textural differences between treatments. Uniform size eel steaks samples from processed pouches were used for the analysis. The samples were compressed twice to $40 \%$ of their original height.

\section{Commercial sterility test}

Thermal processed pouches were tested for commercial sterility as per IS 2168:1971. About four pouches selected at random were incubated at $55^{\circ} \mathrm{C}$ for four days and another four were incubated at $37^{\circ} \mathrm{C}$ for 14 days. The incubated pouches were opened aseptically and samples were transferred into sterile thioglycollate broth (HiMedia) tubes. Then a layer of sterile liquid paraffin wax was poured in each test tube to create anaerobic conditions. The tubes were then incubated at $37^{\circ} \mathrm{C}$ for $48 \mathrm{~h}$ and observed for turbidity development, which indicates the survival of microorganisms. The tubes were further incubated for $48 \mathrm{~h}$ to ascertain sterility.

\section{Sensory test}

Sensory analysis was carried out by a 5 member trained sensory panel using a ten point hedonic scale (Vijayan, 1984).

\section{Storage study}

Storage characteristics of product were evaluated at ambient temperature at $30 \pm 2{ }^{\circ} \mathrm{C}$. The product was analyzed periodically every 30 days for changes in $\mathrm{pH}, \mathrm{TVB}-\mathrm{N}$ and sensory characteristics. $\mathrm{pH}$ value of the fish pieces was determined by AOAC (2005). TVB-N was determined according to Beatty and Gibbons (1936).The characteristics covered under the taste panel was appearance, colour, taste, texture, odour and overall acceptability. A sensory score of 5 taken as the limit of acceptability.

\section{Results and Discussion}

\section{Proximate composition of fresh eel fish meat}

The proximate composition of fresh eel was $77 \pm 0.88$ moisture, $20 \pm 0.5$ crude protein, $1.6 \pm 0.13$ crude fat and $1.5 \pm 0.05 \%$ ash.

\section{Standardization of thermal process parameters for eel steaks in curry in retort pouch}

Heat penetration characteristics of eel in curry processed for 2, 3 and 4 min durations at $121^{\circ}$ $\mathrm{C}$ (Table 2). In all the pouches, the filling weight was maintained at $250 \mathrm{~g}$ per pouch. The sterilization values $\left(\mathrm{F}_{0}\right)$ were estimated to be $5.03,12.89$ and 16.75 respectively. The $F_{0}$ value recommended for thermal processed fish products ranges from 5 to 20 (Pflug and Christensen, 1980; Frott and Lewis, 1994). The slope of heating curve $\left(f_{h}\right)$ values for eel in curry for 2, 3 and 4 min were $8.88,10.15$ and $9.98 \mathrm{~min}$ respectively. The number of minutes required to sterilize at retort temperature (RT) (U) were 5.03, 12.89 and $16.75 \mathrm{~min}$ respectively. The ratio of slope of heating curve to the number of minutes required to sterilize at $\mathrm{RT}$ (i.e. $\mathrm{f}_{\mathrm{h}} / \mathrm{U}$ ) values were 1.24, 0.81 and 0.49 . The final temperature deficit $(\mathrm{g})$ values for eel fish in curry were $0.60,0.52$ and $0.32 \mathrm{~min}$ respectively. The process time (B) taken to achieve thermal processing at $121^{\circ} \mathrm{C}$ for 2,3 and $4 \mathrm{~min}$ were $20.20,12.13$ and $13.19 \mathrm{~min}$. The total process time (TPT), which was found out by adding $42 \%$ of CUT to B varied significantly with change in sterilization value and it was 63.33, 56.66 and $69.00 \mathrm{~min}$ for eel in curry processed at $121^{\circ} \mathrm{C}$ for 2,3 and 4 min 
respectively. The cook value $(\mathrm{Cg})$ increased significantly with $\mathrm{F}_{0}$ value and was 70.17 , 98.67 and 99.99 min respectively.

\section{Texture profile analysis}

The results of TPA of eel steaks in curry processed for 2, 3 and $4 \mathrm{~min}$ (Fig. 1). The toughness/hardness for $\mathrm{F}_{0}$ values of 5.03, 12.89 and $16.75 \mathrm{~min}$ was $4.26 \pm 0.34$,

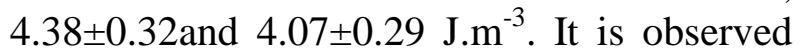
from the result that the toughness decreased as F0 values increased ( $p>0.05)$. This may be due to the effect of prolonged heat treatment on breakdown of connective tissue protein leading to softness of the muscle. The values obtained for cohesiveness for eel in curry were $0.42 \pm 0.06,0.45 \pm 0.06$ and $0.41 \pm 0.06$ for 5.03 , 12.89 and $16.75 \mathrm{~min}$ respectively and showed no significant difference $(\mathrm{p}>0.05)$ when $\mathrm{F}_{0}$ increased. This value is an indication of internal bonding of the muscle cohesiveness in fish in curry. The succulence values obtained for eel in curry product for 5.19, 12.89 and $16.75 \mathrm{~min}$ for processing at $121^{\circ} \mathrm{C}$ were 3.54 , 4.01 and 2.95 g/area respectively. In case of fibrosity, the values for different durations processed at $121^{\circ} \mathrm{C}$ were $7.99,8.36$ and 8.02 respectively. These decreasing trends of texture profiles were mainly due to the increase in the heat treatment (Majumdar et al., 2015). Sreenath et al., (2008) noted the decreasing in texture profile of shrimp curry processed for different $\mathrm{F}_{0}$ values at $121^{\circ} \mathrm{C}$. Majumdar et al., (2015) observed the decreasing trend in texture profile of rohu curry processed at $121.1^{\circ} \mathrm{C}$. Mohan et al., (2006) reported the decreasing trend in texture profile of 'Shrimp Kuruma' in retort pouch and aluminium cans.

\section{Sensory analysis}

The sensory scores observed in the present study, indicated that the overall acceptability scores for eel in curry processed for $12.89 \mathrm{~min}$ gave higher values as compared to product processed for 5.19 and $16.75 \mathrm{~min}$ (Fig. 2). Significant effect was observed on colour of the product. The sensory scores for colour was 8.3 for 12.89 min which was higher than 5.19 (7.4) and 16.75 (7.5) min processed product.

Similarly, score given for test attribute by taste panel was 8.3 for 12.89 min which was higher than $5.19 \mathrm{~min}$ (score 7.8) and $16.75 \mathrm{~min}$ (7.6) processed product. The sensory scores for odour was 9.0 for $12.89 \mathrm{~min}$ which was also higher than 5.19 (8.5) and 16.75 (8.2) min. The scores for texture was 8.4 for $12.89 \mathrm{~min}$ which was higher than 5.19 (7.3) and 16.75 (7.2) min. Ravishankar et al., (2008) carried out sensory evaluation of mackerel curry processed for different $\mathrm{F}_{0}$ values i.e. 7, 8 and 9 min. Similarly, Dhanapal et al., (2010) observed the sensory scores for tilapia fish paste processed for different $\mathrm{F}_{0}$ values i.e. 6, 7 , 8 and 9 min, Abhilash et al., (2013) observed the sensory score of crab koftha processed for different $\mathrm{F}_{0}$ values of 5,6 and $7 \mathrm{~min}$ and sensory score for rohu curry processed for different $F_{0}$ values of 7,8 and 9 as observed by Majumdar et al., (2015).

Based on the commercial sterility, sensory evaluation and texture profile analysis, $\mathrm{F}_{0}$ value of $12.89 \mathrm{~min}$ for $3 \mathrm{~min}$ duration was found satisfactory for the preparation of eel steaks in curry in retort pouches (Table 3 and Fig. 3). The product was kept for storage study to evaluate the shelf life at ambient temperature $\left(30 \pm 2^{\circ} \mathrm{C}\right)$.

\section{Storage studies of eel steaks in curry in retort pouch}

\section{Changes in biochemical characteristics}

The change in the $\mathrm{pH}$ values of eel curry during storage at ambient temperature (Table 4). The $\mathrm{pH}$ values of eel steaks in curry decreased from 6.7 to 5.8 during storage. 
Table.1 Recipe of standardized curry medium

\begin{tabular}{|c|l|c|}
\hline Sr. No. & \multicolumn{1}{|c|}{ Ingredient } & Quantity \\
\hline $\mathbf{1}$ & Fresh eel & $400 \mathrm{~g}$ \\
\hline 2 & Raw coconut & $3 / 4 \mathrm{size}$ \\
\hline 3 & Green chilly & $10 \mathrm{~g}$ \\
\hline 4 & Dried whole red chilly & $10 \mathrm{~g}$ \\
\hline 5 & Garam masala mix & $20 \mathrm{~g}$ \\
\hline $\mathbf{6}$ & Turmeric powder & $1 \mathrm{~g}$ \\
\hline $\mathbf{7}$ & Coriander Seed & $10 \mathrm{~g}$ \\
\hline $\mathbf{8}$ & Onion & $1 \mathrm{no}$ \\
\hline $\mathbf{9}$ & Garlic, Ginger & $6 \mathrm{pieces}$ \\
\hline $\mathbf{1 0}$ & Refined oil & $100 \mathrm{ml}$ \\
\hline 11 & Salt & $12 \mathrm{~g}$ \\
\hline $\mathbf{1 2}$ & Semi-dried kokam (Gracinia indica) & $4 \mathrm{pieces}$ \\
\hline 13 & Chirphal powder (Zanthoxylum rhetsa) & $2 \mathrm{~g}$ \\
\hline 14 & Fresh coriander leaves & $2 \mathrm{~g}$ \\
\hline 15 & Water & 200 \\
\hline
\end{tabular}

Table. 2 Heat penetration characteristics of eel steaks in curry processed at $121^{\circ} \mathrm{C}$

\begin{tabular}{|c|l|c|c|c|} 
Sr. No. & \multicolumn{1}{|c|}{$\begin{array}{c}\text { Heat penetration } \\
\text { characteristics }\end{array}$} & \multicolumn{3}{|c|}{ Processing duration } \\
\hline $\mathbf{1}$ & $\mathrm{F}_{\mathrm{o}}$ & $\mathbf{2}$ min & $\mathbf{3}$ min & $\mathbf{4}$ min \\
\hline $\mathbf{2}$ & $\mathrm{f}_{\mathrm{h}}(\mathrm{min})$ & $5.03 \pm 0.07$ & $\mathbf{1 2 . 8 9} \pm \mathbf{0 . 7 9}$ & $16.75 \pm 1.33$ \\
\hline $\mathbf{3}$ & $\mathrm{U}(\mathrm{min})$ & $8.88 \pm 0.36$ & $\mathbf{1 0 . 1 5} \pm \mathbf{0 . 5 0}$ & $9.98 \pm 0.37$ \\
\hline $\mathbf{4}$ & $\mathrm{f}_{\mathrm{h}} / \mathrm{U}$ & $1.03 \pm 0.71$ & $\mathbf{1 2 . 8 9} \pm \mathbf{0 . 7 9}$ & $16.75 \pm 1.33$ \\
\hline $\mathbf{5}$ & $\mathrm{g}{ }^{\circ} \mathrm{C}$ & $0.60 \pm 0.04$ & $\mathbf{0 . 8 1} \pm \mathbf{0 . 0 3}$ & $0.49 \pm 0.05$ \\
\hline $\mathbf{6}$ & $\mathrm{Cg}(\min )$ & $70.17 \pm 0.53$ & $\mathbf{0 . 5 2} \pm \mathbf{0 . 0 2}$ & $0.32 \pm 0.05$ \\
\hline $\mathbf{7}$ & $\mathrm{B}(\min )$ & $20.22 \pm 0.60$ & $\mathbf{9 8 . 6 7} \pm \mathbf{2 . 1 3}$ & $99.99 \pm 2.53$ \\
\hline $\mathbf{8}$ & $\mathrm{CUT}(\min )$ & $10.73 \pm 0.29$ & $\mathbf{8 . 2 2} \pm \mathbf{0 . 4 1}$ & $13.19 \pm 0.29$ \\
\hline $\mathbf{9}$ & TPT & $63.33 \pm 7.26$ & $\mathbf{5 6 . 6 6} \pm \mathbf{7 . 2 6}$ & $6.79 \pm 0.32$ \\
\hline
\end{tabular}

(All values are expressed as mean \pm standard error)

$\mathrm{F}_{0^{-}}$Sterilization value, fh- slope of heating curve, U- Time in min for sterilization at retort temperature, g- Final temperature, B- Process time, CUT- Come up time, $\mathrm{Cg}$ - Cook value, TPT- Total process time

Table.3 Heat penetration characteristics of eel in curry product processed for 3 min at $121^{\circ} \mathrm{C}$

\begin{tabular}{|l|c|c|}
\hline Sr. No. & Process parameters & Processed for $\mathbf{3}$ min duration \\
\hline $\mathbf{1}$ & $\mathrm{F}_{0}$ & 12.89 \\
\hline $\mathbf{2}$ & $\mathrm{fh}(\mathrm{min})$ & 10.15 \\
\hline $\mathbf{3}$ & $\mathrm{U}$ & 12.89 \\
\hline $\mathbf{4}$ & $\mathrm{fh} / \mathrm{U}$ & 0.81 \\
\hline $\mathbf{5}$ & $\mathrm{g}^{\circ} \mathrm{C}$ & 0.52 \\
\hline $\mathbf{6}$ & $\mathrm{Cg}(\mathrm{min})$ & 98.67 \\
\hline $\mathbf{7}$ & $\mathrm{B}(\mathrm{min})$ & 12.13 \\
\hline $\mathbf{8}$ & $\mathrm{CUT}$ & 8.22 \\
\hline $\mathbf{9}$ & $\mathrm{TPT}$ & 56.66 \\
\hline
\end{tabular}


Table.4 Changes in $\mathrm{pH}$ values of eel in curry product during storage at ambient temperature

\begin{tabular}{|c|c|}
$\begin{array}{l}\text { Storage } \\
\text { period (Months) }\end{array}$ & pH \\
\hline 0 & $6.6 \pm 0.1$ \\
\hline 1 & $6.4 \pm 0.1$ \\
\hline 2 & $6.2 \pm 0.1$ \\
\hline 3 & $6.1 \pm 0.1$ \\
\hline 4 & $6.1 \pm 0.1$ \\
\hline 5 & $6.0 \pm 0.5$ \\
\hline 6 & $5.9 \pm 0.1$ \\
\hline 7 & $5.8 \pm 0.1$ \\
\hline 8 & $5.7 \pm 0.1$ \\
\hline
\end{tabular}

Table.5 Changes in TVB-N content of eel in curry product during storage at ambient temperature

\begin{tabular}{|c|c|}
\hline $\begin{array}{c}\text { Storage period } \\
\text { (Months) }\end{array}$ & TVB-N \\
\hline 0 & $4.20 \pm 0.30$ \\
\hline 1 & $5.57 \pm 0.06$ \\
\hline 2 & $6.12 \pm 0.35$ \\
\hline 3 & $6.83 \pm 0.13$ \\
\hline 4 & $7.68 \pm 0.17$ \\
\hline 5 & $9.48 \pm 0.53$ \\
\hline 6 & $12.03 \pm 0.10$ \\
\hline 7 & $14.03 \pm 0.71$ \\
\hline 8 & $17.07 \pm 0.17$ \\
\hline
\end{tabular}

Fig.1 Texture profile attributes of eel steaks in curry processed for 2,3 and 4 min at $121^{\circ} \mathrm{C}$

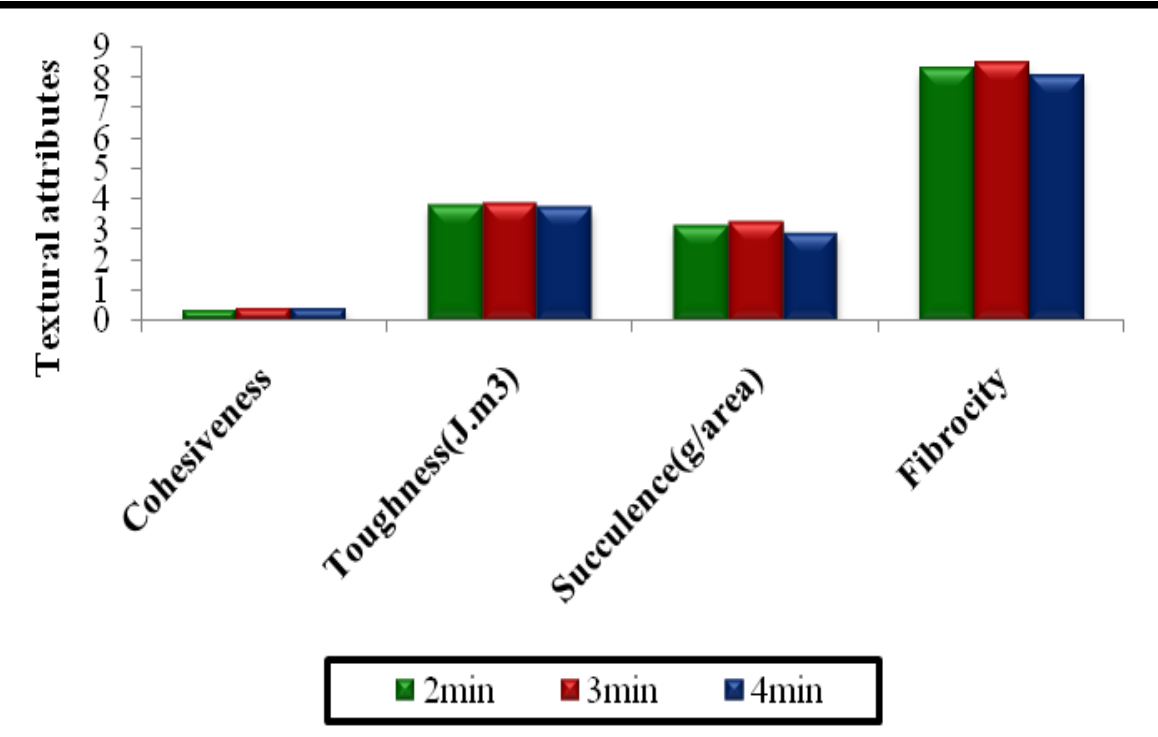


Fig.2 Sensory characteristics of eel steaks in curry processed for 2,3 and 4 min at $121^{\circ} \mathrm{C}$

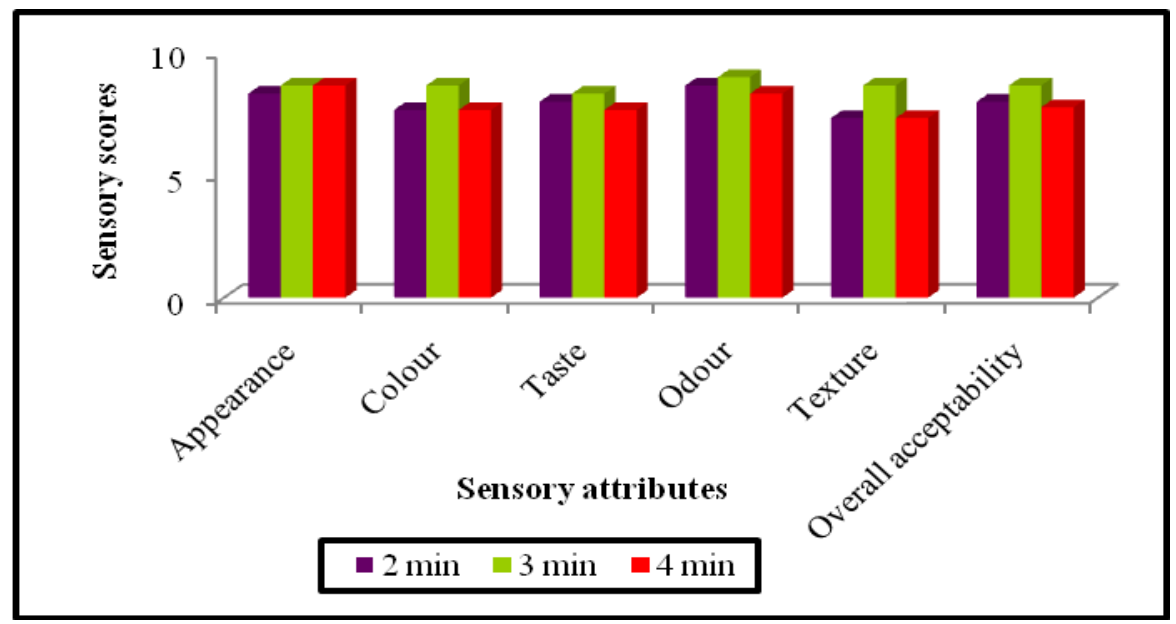

Fig.3 Heat penetration characteristics of eel steaks in curry processed for $3 \mathrm{~min}$

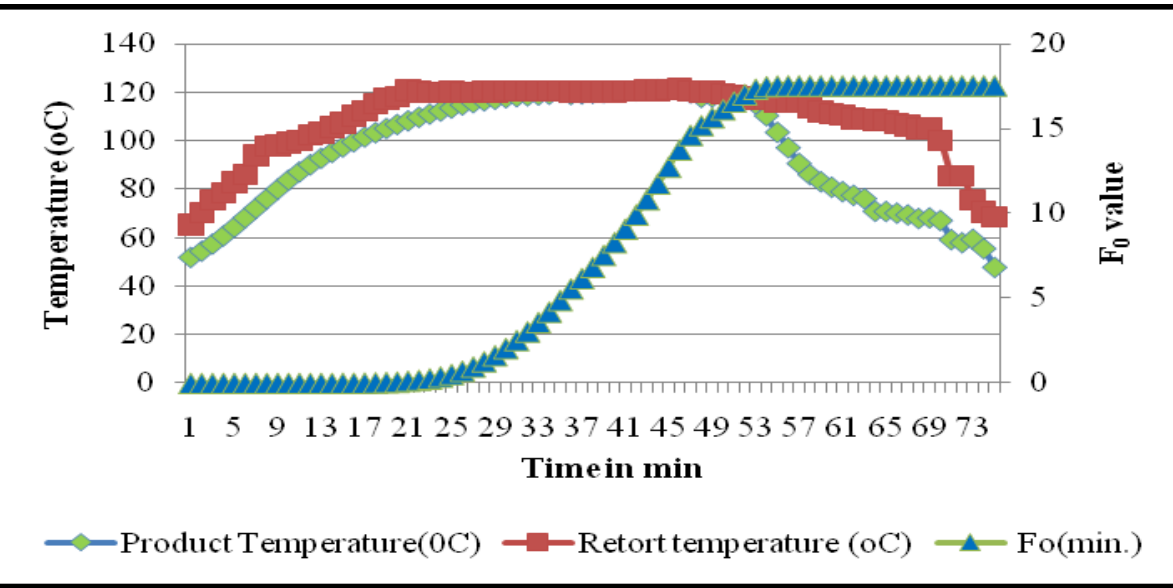

Fig.4 Changes in sensory score of eel steaks in curry during storage at ambient temperature

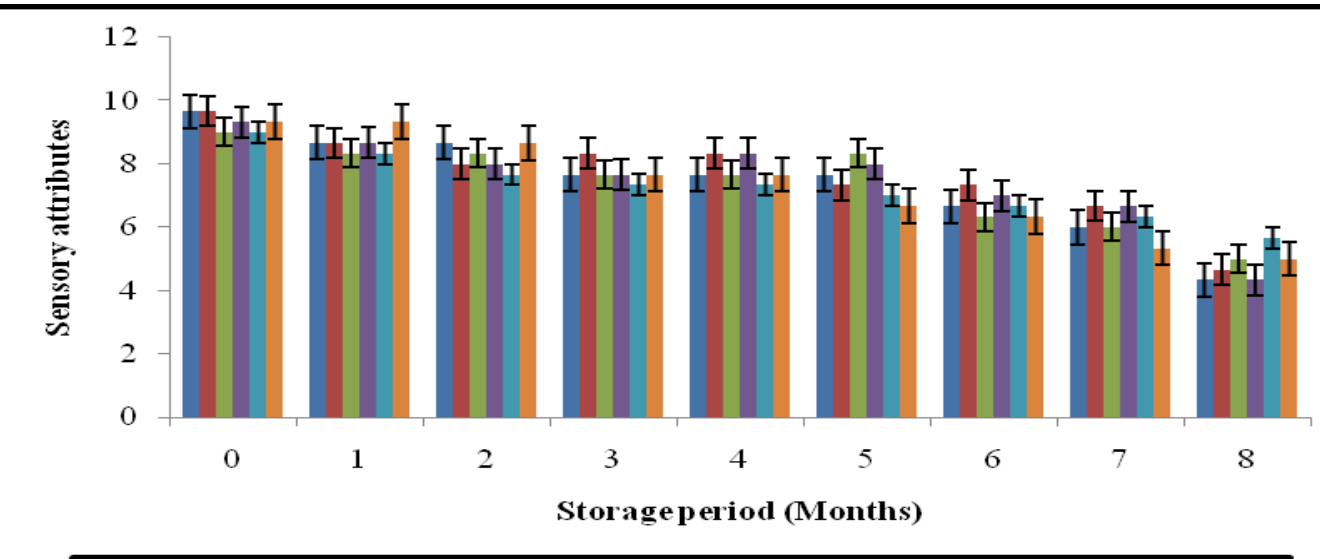

Appearance $\square$ Colour $\square$ Taste $\quad$ Odour $\square$ Texture $\square$ Overall acceptability 
The commonly observed decrease in $\mathrm{pH}$ might be due to degradation of proteins and liberation of free amino acids (Rajan et al., 2011). The results are in accordance with the studies conducted by Mohan et al., (2006) has reported a slight reduction in the $\mathrm{pH}$ of shrimp kuruma upon storage in both retort pouch and aluminium cans.In case of mackerel curry packed in retort pouch, Mallick et al., (2006) observed decrease in $\mathrm{pH}$ values from 5.8 to 5.43 at room temperature and 5.65 to 5.55 at $37^{\circ} \mathrm{C}$ during 6 months storage of rohu in curry medium using polyester-coated tin free steel cans. Similarly Ravishankar et al., (2008) and Tribuzi et al., (2015) observed decreasing trend in $\mathrm{pH}$ values from 5.5 to 5.25 and 6.72 to 6.63 during 12 months storage of Goan style mackerel curry in retort pouch and 52 weeks storage of chopped mussel meat in retort pouch respectively.

The TVB-N values of eel steaks in curry increased progressively from initial values of 4.2 to $17.07 \mathrm{mg} \%$ at the end of 8 months of storage at ambient temperature (Table 5). This may be attributed to the breakdown of proteins, amino acids and other nitrogenous compounds during thermal processing (Kovalchuk, 1954). Dileep et al., (2012) observed increase in TVB-N content from 20 to $24.3 \mathrm{mg} \%$ in thermal processed squid rings in curry medium during 90 days at ambient temperature. Akande and Faturoti (2009) also noted increase in TVB-N content from 25.94 to $45.63 \mathrm{mg} \%$ and 22.17 to $42.37 \mathrm{mg} \%$ in canned Bonga in oil and also in tomato sauce respectively during 36 months of storage in cans. Chandra et al., (2012) observed the increase in TVB-N content of ribbon fish in TFS cans from 4.55 to $20.18 \mathrm{mg} \%$ during 5 months of storage. Dinakaran et al., (2017) reported increase in TVB-N values of mackerel curry in semi rigid containers from $14 \mathrm{mg} \%$ in the $1^{\mathrm{st}}$ month to $34.7 \mathrm{mg} \%$ in the $14^{\text {th }}$ month of storage.

\section{Changes in sensory characteristics}

Sensory evaluation of eel in curry processed for 3 min of $\mathrm{F}_{0}$ value of 12.89 at $121^{\circ} \mathrm{C}$ was carried out at an interval of 30 days (Fig. 4) The score for appearance decreased from 9.67 to 4.33 at the end of 8 months of storage. The score for colour decreased from 9.67 to 5.78 at the end of storage. The score given for taste also decreased from 9.00 to 5.00 at the end of storage. Sensory score for odour was lowered from 9.33 to 4.33 at the end of storage. The score for texture decreased gradually from 9.00 to 5.67 at the end of storage. The sensory score for overall acceptability decreased from 9.67 to 5.00 at the end of storage. The visual observations of the product revealed that, colour of the product did not change and texturally the fish steaks were intact up to $6^{\text {th }}$ month of storage, after that the colour of the curry faded out towards the end of the storage. These observations were reflected in the colour score of the product as the colour score decreased drastically towards the $8^{\text {th }}$ month of the storage. Moreover, there was disintegration of the fish steaks towards the end of the storage which was observed in the $7^{\text {th }}$ month of storage in the eel in curry packs. Decreasing trend in sensory scores during storage of thermal processed product have been reported by Gopal et al., (2001) for traditional style mackerel curry, Mallick et al., (2006) in rohu cury, Bindu et al., (2007) in clam meat and Ravishankar et al., (2008) in Goan style mackerel curry. Dileep et al., (2012) noted the sensory analysis for squid ring in curry in retort pouch and showed a marginal decrease in all attributes after a period of 90 days of storage.

The retort pouches are suitable for packing eel curry. The biochemical and sensory characteristics of the product were satisfactory during storage. Eel curry processed for 3 min duration with an $\mathrm{F}_{0}$ value of $12.89 \mathrm{~min}$ was found to be ideal with 
respect to all the parameters. The product was found to have storage stability at ambient temperature $\left(30 \pm 2^{\circ} \mathrm{C}\right)$ with desirable organoleptic characteristics.

\section{References}

Abhilash, S., Sreenath, P. G., Ravishankar, C. N. and Srinivasa Gopal, T. K. 2013. Standardization of process parameters for ready-to-eat crab koftha in indigenous polymer-coated tin-free steel cans. Fish. Technol., 50: 154-160.

Akande, G. R. and Faturoti, E. O. 2009. Chemical composition and quality changes in bonga (Ethmalosa fimbriata) canned in oil and tomato sauce. Fish. Technol, 46 (1): 39-44.

AOAC. 2005. Official methods of analysis of the Association of Official Analytical Chemists International, $18^{\text {th }}$ edition, In: Horwitz, W. (Ed.), Association of Official Analytical Chemists, Washington (D. C.), 35: 2-36.

Beatty, S.A. and Gibbons, N. E. 1936. The measurement of spoilage in fish. J. Biol. Bd.Can., 3: 77-91.

Bindu, J., Ravishankar, C. N. and Gopal, T. K. S. 2001. Thermal processing of ready to serve masmin curry from skipjack tuna in opaque retortable pouches. Coastal Fishery Resources if India - Conservation and Sustainable Utilisation. Pp. 529-539.

Bindu, J., Ravishankar, C. N. and Gopal, T. K. S. 2007. Shelf life evaluation of a ready to eat black clam (Villorita cyprinoides) product in indigenous retort pouches. J. Food Engg. 78: 9951000.

Bindu, J., Ravishankar, C. N., Dinesh, K., Mallick, A. K. and Gopal, T. K. S. 2011. Heat penetration characteristics and shelf life of ready to serve mahseer curry in opaque retortable pouches. Fish. Technol. 48 (2): 141-148.
Chandra, M. V., Raju, C. V. and Vijay Kumar Reddy, S. 2012. Influence of heat penetration on the quality of canned ribbon fish (Trichiurus lepturus). J. Food Process. Presv.38: 807-814.

Cheret, R., Chapleau, N., Delbarre-Ladrat, C., Verrez-Bagnis, V. and De Lamballerie, M. 2005. Effect of high pressure on texture and micro structure of sea bass (Dicentrachus labrax L) fillets. J. Food Sci., 70(8): 477-483.

Dhanapal. K., Reddy, G. V. S., Nayak, B. B., Basu, S., Shashidhar, K., Venkatesharlu, G. and Chouksey, M. K. 2010. Quality of ready to serve tilapia fish curry with PUFA in retortable pouches. J. Food Sci. 75 (7): 348-354.

Dileep, A. O., Sudhakara, N. S. and Basavakumar, K. V. 2012. Storage studies of retortable pouch processed squid (Loligo duvaucelli) rings in curry medium. Fish. Technol. 49: 54-58.

Dinakaran, A., Mohan, C. O., Panda, S., Ravishankar, C. N. and Srinivasa Gopal, T. K. 2017. Development of ready-to-eat Indian mackerel curry (Rastrilliger kanagurta) in semi rigid containers using water spray retort. In: Fostering Innovations in Fisheries and Aquaculture: Focus on Sustain ability and Safety- Book of Abstracts, $11^{\text {th }}$ Indian Fisheries and Aquaculture Forum, ICAR- Central Institute of Fisheries Technology, Kochi and Asian Fisheries Society, Indian Branch, 21-24 Nov., 2017, Kochi, India, pp. 354.

Frott, R, and Lewis, A.S. 1994. In: R. Frott and AS lewis (Eds) Canning of meat and Fish Products (202). UK: Chapman and Hall.

Gopal, T. K. S., Joseph, J., Balachandran, K. K. and Govindan, T. K. 1986. Development of flexible packages for fish pickles. Packag. Ind. 27 (1): 5-8.

Gopal, T. K. S., Vijayan, P. K., Balachandran, K. K., Madhavan, P. and Iyer, T. S. G. 
2001. Traditional Kerala style fish curry in indigenous retort pouch. Food Control. 12: 523-527.

IS 2168 1971. Specification for pomfret canned in oil. Indian Standards Institute, New Delhi, India.

Koval'chuk, G. K. 1954. Alteration of muscle proteins of fish in heat treatment (In Russian). Trudy Koskov Techno Inst Rybnoi Pomi Kho. 6: 139-159.

Kumar, R., Johnsy, G., Rajamanickam, R., Lakshmana, J. H., kathiravan, T., Nataraju, S. and Nadanasabapathi, S. 2013. Effect of gamma irradiation and retort processing of microbial, chemical and sensory quality of ready-to-eat (RTE) chicken pulav. International Food Research Journal 20(4): 15791584.

Madhawaraj, M. S., Sathish, H. S., Rao, A. R. V., Rao, G. C. P. R. and Mahendrapandian, S. 1992. Steam-flush water seal technique for removal of headspace air in retort pouches to near zero levels. Lebensm. Wiss. U. Technol., 25: 87.

Majumdar, R. K., Dhar, B., Roy, D. and Saha, A. 2014. Optimization of thermal processing of catla fish curry in retort pouch. J. Food Preser. Proces, 39 (6): 1595-1604.

Majumdar, R. K., Dhar, B., Roy, D. and Saha, A. 2015. Optimization of process conditions for rohu fish in curry medium in retortable pouches using instrumental and sensory characteristics. J. Food Sci.Technol., 52 (9): 56715680.

Mallick, A. K., Gopal, T. K. S., Ravishankar, C. N. and Vijayan, P. K. and Geethallakshmi, V. 2010. Changes in instrumental and sensory properties of Indian white shrimp in curry medium during retort pouch processing at different $\mathrm{F}_{\mathrm{o}}$ values. J. Text. Stud., 41: 611-632.
Mallick, A. K.,Gopal, T. K. S., Ravishankar, C. N. and Vijayan, P. K. 2006. Canning of rohu (Labeo rohita) in north Indian style curry medium using polyester coated Tin Free Steel cans. Food Sci. Tech Int, 12 (6): 539-545.

Manju, S., Sonaji, E. R., Leema, J., Gopal, T.K.S., Ravishankar, C.N and Vijyan, P.K. 2004. Heat penetration characteristics and shelf life studies of seer fish moilee packed in retort pouch. Fish. Technol. 41: 37-44.

Mohan, C. O., Ravishankar, C. N, Bindu, J., Geethalakshmi, V. and Gopal, T. K. S. 2006. Effect of thermal process time on quality of kurma shrimp in retortable pouches and aluminum cans. J. Food Sci., 71 (2): 496-500.

Patange, S. B., Shrangdhar, S. T. and Patil, S. S. 2016. Packaging technology for traditional konkan style mackerel fish curry. Proceedings of $2^{\text {nd }}$ national conference on recent advances in science and technology, 483-485.

Pflug, I. J. and Christensen, R. 1980. Converting an F-value determined on the basis of one $\mathrm{z}$-value to an F-value determined on the basis of another $\mathrm{Z}$ value. J. Food Sci., 45(1): 30-35.

Rajan, S., Kulkarni, V. V. and Chandirasekaran, V. 2011. Preparation and storage stability of retort processed Chettinad chicken. J.FoodSci.Technol., 51: 173-177.

Ravishankar, C. N., Bindu, J. and Gopal, T. K. S. 2008. Ready to serve mackerel curry (Goan style) in retortable pouches, Fish. Technol. 45(2):171-180.

Ravishankar, C. N., Gopal, T. K. S. and Vijayan, P. K. 2002. Studies on heat processing and storage of seer fish curry in retort pouches, Packag. Technol. Sci. 15:3-7.

Sreenath, P. G., Abhilash, S., Ravishankar, C. N. and Srinivasa Gopal, T. K. 2008. Standardization of process parameters 
for ready-to-eat squid masala in indigenous polymer-coated tin-free steel cans. J. Food Process. Preserv. 32: $247-$ 269.

Stumbo, C. R. 1973. Thermobacteriology in Food Processing, $2^{\text {nd }}$ edn, 236, Academic Press. Inc. New York.

Szczesniak, A. S. 2002. Texture is a sensory property. Food Qual. Prefer., 13: 215225.

Tribuzi, G., Aragao, G. M. F. D. and Laurindo, J. B. 2015. Processing of chopped muscle meat in retort pouch. Food Sci. Technol., 35 (4): 612-619.

Vijayan, P. K. 1984. Report on training programme on retortable pouch processing of fish and fish analysis at Tropical Development and Research Institute and Metal Box (R\&D), UK, Cochin: Central Institute of Fisheries Technology.
Vijayan, P. K. and Balachandran, K. K. 1986. Development of canned fish curry. Fish. Technol. 23: 57-60.

Vijayan, P. K., Srinivasa Gopal, T. K., Balachandran, K. K. and Madhavan, P.1998. Fish curry in retort pouch. In: Advances and Priorities in Fisheries Technology (Balachandran, K. K., Iyer, T. S. G., Madhavan, P., Joseph, J., Perigreen, P. A., Raghunath, M. R. and Varghese, M. D., Eds), 232-235, Society of Fisheries Technologists (India), Cochin.

Xavier, K. A. M., Ravishankar, C. N., Bindu, J. and Gopal, T. K. S. 2013. Textural and colour changes of mackerel (Rastrelliger kanagurta) thermal processed at different retort temperatures. Fish. Technol., 50:133138.

\section{How to cite this article:}

Rohini Mugale, S.B. Patange, V.R. Joshi, G.N. Kulkarni and Shirdhankar, M.M. 2018. Heat Penetration Characteristics and Shelf Life of Ready to Serve Eel Curry in Retort Pouch. Int.J.Curr.Microbiol.App.Sci. 7(02): 89-100. doi: https://doi.org/10.20546/ijcmas.2018.702.012 